\title{
FOLR2 wt Allele
}

National Cancer Institute

\section{Source}

National Cancer Institute. FOLR2 wt Allele. NCI Thesaurus. Code C104915.

Human FOLR2 wild-type allele is located within 11q13.3-q14.1 and is approximately $5 \mathrm{~kb}$ in length. This allele, which encodes folate receptor beta protein, plays a role in the internalization of folic acid. 